\title{
The problems of the effective classroom teaching in Govt. colleges in Dhaka City
}

\author{
M. Roungu Ahmmad \\ Faculty Member, Department of Statistics, Jagannath University, Dhaka-1100, Bangladesh \\ Email address: \\ m.roungu_sbi_du@yahoo.com
}

\section{To cite this article:}

M. Roungu Ahmmad. The Problems of the Effective Classroom Teaching in Govt. Colleges in Dhaka City. Humanities and Social Sciences. Vol. 2, No. 2, 2014, pp. 17-22. doi: 10.11648/j.hss.20140202.12

\begin{abstract}
This study is undertaken to study the present status of current teaching-learning system and to identify the limitations of the effective classroom teaching in Govt. colleges. Teachers have been facing various kinds of problems for a long time in Govt. colleges. But it is very difficult to throw light on all the problems within a very short time. The problems are like teachers are not provided with modern teaching aid; they can't follow a specific teaching method. Lesson plan is not prepared regularly, Classroom problem, Political instability etc. Also, there is a shortage of trained teachers; authorities are not supportive to the teachers' demand in the classroom and laboratory. Finally, some recommendations have been given to ensure effective classroom teaching.
\end{abstract}

Keywords: Teaching-Learning System, Effective Classroom, Classroom Teaching

\section{Introduction}

It is said that education is the backbone of a nation. By education, a man can grow with a certain vision, quality and competence. In the context of teaching method or up to date classroom teaching is not yet satisfactory in Govt. colleges in Dhaka city, Bangladesh. In Govt. colleges, the classroom condition is simply unsatisfactory. No updated teaching system has been implemented in those colleges.

\subsection{Statement of the Problem}

Teaching - learning process is the most important factor for improving the quality education which depends mostly on the classroom teaching. So, classroom teaching should be effective. In this study, we have to find out some limitations of the effective classroom teaching and recommend the ways of solution. Better teaching-learning system ensures quality education and quality education mostly depends on the effective classroom teaching. Having done this study, some problems are identified regarding effective classroom teaching and some ways and means are recommended to overcome those problems for proper teaching-learning system.

\subsection{Objectives of the Study}

I have taken this study with the following objectives:
1. To study the present status of current teachinglearning system in Govt. colleges.

2. To identify the limitations of the effective classroom teaching in Govt. colleges.

3. To find out some measures to implement the effective classroom teaching in Govt. colleges.

Better teaching-learning system ensures quality education and quality education mostly depends on the effective classroom teaching. Having done this study, some problems are identified regarding effective classroom teaching and some ways and means are recommended to overcome those problems for proper teaching-learning system.

\section{Literature Review}

Review of related literature is an essential part of a research work. It gives researchers good background of information about the concept of the area and methodology in which research should be conducted. With this view, I tried to make a creative review. It is found that a good number of research works have been conducted both in home and abroad. For convenience the reviewed information has been divided into two groups.

Copper (1970) stated that visual and aural aids can be helpful to the teachers of a foreign language in a number of different ways. They can brighten up the classroom and 
bring more variety and interest into - Language lesson, Visual aids in particular can help to provide the situations which light up the meaning of the utterances used, Aural aids in particular can help the teacher to improve his grasp of foreign language and to prepare more effective lessons., Both aural and visual aids can stimulate students to speak the language as well as to read and write it.

Du (2002) noted that among the problems existing in college teacher's class load is the key issue. Human behavior is the most complex phenomenon. Teachers with highly practical vision, strategies, skills and knowledge can manage classroom effectively (Tan, Parsons, Hinson, and Sardo-Brown, 2003). The term classroom management refers to all those decisions that teachers take to facilitate the learning process and tp provide the students maximum opportunity for learning (Krause, Bochner, and Duchesne, 2003). In words of Berliner (1988) classroom management includes all those essential activities which are important to maintain an environment which generates necessary and positive conditions for learning. To achieve this purpose, teachers may plan rationally for their lessons, prepare teaching and learning materials more judiciously, organize the content, decorate classroom and establish daily routines. The basic purpose of classroom management according to Froyen and Iverson (1999) aims to encourage students towards learning and to promote their positive behaviors. These writers further argue that positive classroom management contributes to enhanced academic achievements of students, increased teacher efficacy, improved students behavior and teachers teaching. Feldman (1997) considers classroom management not only related to management of students' behavior but also to lesson planning of teacher, organizing of the materials, controlling of behaviors, goal based learning process, supportive atmosphere and maintaining a highly effective teaching and learning experiences within classrooms.

All these form important characteristics of the teaching and learning experiences. Hence, in the words of Krause, Bochner and Duchesne (2003) a classroom where a teacher creates an environment which enables the students to know the effective use of the available timeand its resources and also cooperate with their class fellows is called real community of learners. According to Ostrosky, Jung, Hemmeter and Thomas (2008) in the development of a positive classroom environment a teacher plays a highly important role. Teachers can create such conditions inside the classrooms where students feel safe and learn how to work together effectively as individuals. Here, the role of the teachers is to maximize learning and minimize disruptions by fostering among students attitudes of trust, tolerance, acceptance and cooperation. In this regard Canter and Canter. (2001) argue that there are two goals of classroom management, first, to create and maintain a highly supportive learning environment and second, to promote a safe classroom community so that students' interest, motivation and involvement in the learning process is ma entrained.
This situation will enable to discuss their needs with teachers without and also feel comfortable to intellectual risks. For this purpose teachers can establish rules and routines. Additionally, Edwards (2004) has found that rules and routines provide students with structure to work in organization and interact with each other fairly. The class rules and routines must be mentioned both verbally and in written form. Examples should be shared wherever necessary by the teachers through modeling during teaching and learning. The basic purpose of classroom management is socialization of students. It depends on the environment prevailing in the school. Positive environment directs students' behavior in a positive manner. Teachers should direct students' behavior in a desirable way. Whenever there is any disturbance in the classroom, teachers may take help from experts and develop better strategies to cope with particular students with inappropriate behaviors.

For successful teaching and learning teachers need to plan effectively. Successful classroom teaching plan supports teachers in successful classroom management. For this purpose, Ingersoll and Smith (2003) suggest six strategies such as reflecting on student development needs, creating a supportive physical environment, creating a cooperative learning environment, teaching and maintaining rules and procedures, managing classroom activities effectively, promoting sense of cooperation among students, using appropriate classroom management style. According to Dreikurs, Grunwald and Pepper (1998) the goal of classroom management is considering and satisfying students' developmental needs. This purpose can be achieved by creating conducive learning environment, stimulating sights, relax sounds and good ventilation. In view of Feldman (1998) classroom is a place where students should feel comfortable and at ease.

The surrounding of the classroom should be neat and clean. There should be respect for each other and a nonthreatening atmosphere. Effective teachers create a classroom management which is based on engaging practices. Such teachers set expectations for their students such as respect for rules and procedures and a motivating learning climate where every student takes part with interest. Management of physical environment is a major task for teacher. It includes arrangement of desks, resources and teaching equipments. Physical management of classroom is closely related to students' behavior. Hence, teachers should think about the preparation of physical resources when they plan. They can change it according to their needs goals and choose whatever works best for them (Eggen and Kauchak, 2004). Teachers usually encounter disciplinary problems during classroom teaching process. One of the best ways to deal with behavior problems is establishment of classroom rules and procedures. Procedures help teachers in establishing routines for students for example turning papers, asking for questions, sharpening pencils, doing group or pair activities. Rules provide sense of regularity and organization for studentsand 
teachers. Classroom management is organizing space, time and materials to facilitate effective instruction. It is a highly difficult task, because a teacher has to cope with many students with individual differences. They have different interest and choices (Wong and Rosemary, 2001). According to Santrock (2006) teacher must be ready to attend to students' individual learning needs. For this the teacher can actively monitor the teaching learning process by creating an engaging environment. Hence, teachers can actively monitor students by watching them closely, giving feedback to correct undesirable behaviors and to praise for good behaviors. Jones (2000) elaborates that the use of communication pattern is an important variable in classroom management. Gieger (2000) argues that clear communication between teachers and students minimizes the chances of misunderstanding. This will lead to less discipline problems in the classroom. For maintaining good discipline behavior management is a necessary. Hence, teachers must show firmness, tenderness and gentleness to deal with students' misbehavior. Nayak and Rao (2008) suggest that teachers must make the students realize their own behaviors for wrong doings or right. This will develop in students the habit of self-discipline. Insummary it can be said in the words of Tan (2001) that for maintaining a good classroom environment and for solutions of classroom problems, teachers must create conducive learning environment where students find respect, care, meaning and opportunity for personal and social growth. For this purpose, both teachers and students should be able to interact with each other easily under the established rules, procedures and regulations.

\subsection{Studies Conducted in Bangladesh}

Selim and Mahboob (2001) mentioned that the main cause of failure in English lies in the defective method of teaching. The syllabus and teaching materials are designed in such a rigid manner that there hardly any scope for flexibility in them. Teachers have no liberty to do anything creative or experimental. The next cause is lack of teaching materials. As the teachers are only provided with the textbooks and no teacher's book, they do not follow method of teaching.

\subsection{Methodology}

Research is a systematic process. The essential step of a research work is to design the method, which leads the researchers in a proper way. The present study has been designed by the methods in a logical and scientific manner.

Data were collected from the primary sources. For collection of data, investigator first need to choose a wide variety of data gathering tools like interview, observations, questionnaire, checklist, rating scale etc. For this study questionnaire was used as a foremost tool. Questionnaires were distributed to the teachers in the Govt. colleges of $116^{\text {th }}$ FTC, NAEM. Data were collected and processed and then presented in tabulated form. Then analysis and interpretations of data have been done which have been presented elaborately in the next three chapters.

\subsection{Present Status of Current Teaching-Learning System in Govt. Colleges}

Some primary data have been collected from 500 respondents who are teaching in different Govt. colleges in Dhaka City area. These data are shown below in the form of tables.

Table 1. Distribution about facing problem in the classroom and types of problem faced while teaching in the classroom

\begin{tabular}{lll}
\hline Type & No. Respondents & Percentage \\
\hline Yes & 420 & $84 \%$ \\
No & 080 & $16 \%$ \\
Types of problem faced while teaching in the classroom \\
\hline Infrastructure problem & 090 & $18 \%$ \\
Lack of teaching aid & 150 & $30 \%$ \\
Absence of student & 280 & $56 \%$ \\
\hline
\end{tabular}

From the above table and below diagram, we see that about $84 \%$ respondents face problems in the classroom and students' absenteeism is the main problem in the classroom teaching.

Table 2. The distribution about seating capacity and types of presence of students.

\begin{tabular}{lcc}
\hline Type & No. Respondents & Percentage \\
\hline Less than 50 & 160 & $32 \%$ \\
$50-60$ & 240 & $48 \%$ \\
Above 60 & 100 & $20 \%$ \\
Types of presence of students in the classroom & 050 & $30 \%$ \\
\hline Regular & 300 \\
Irregular & 150 \\
Sometimes regular & $30 \%$ \\
\hline
\end{tabular}


About facing problem in the classroom

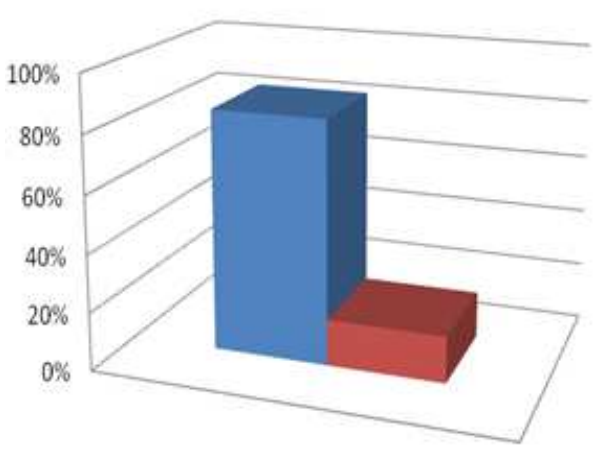

Types of problem faced while teaching in the classroom

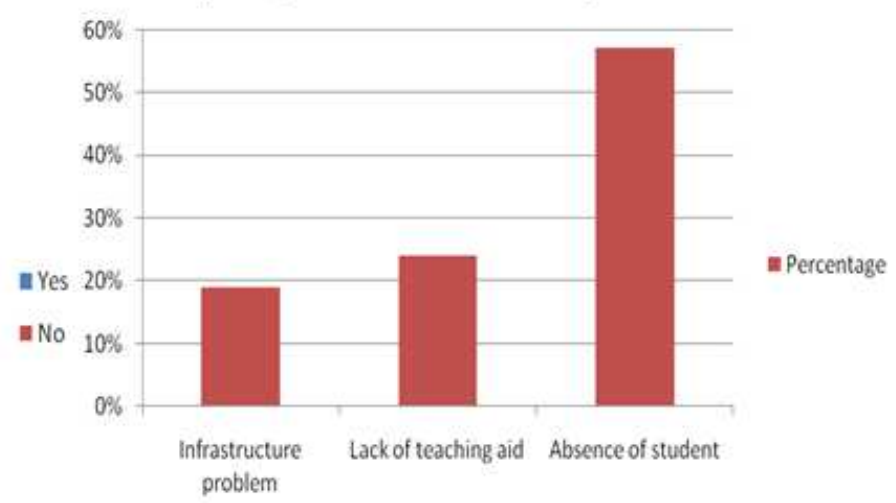

Fig 1. About facing problem in the classroom and types of problem faced while teaching in the classroom

\section{About seating capacity in the classroom Percentage}

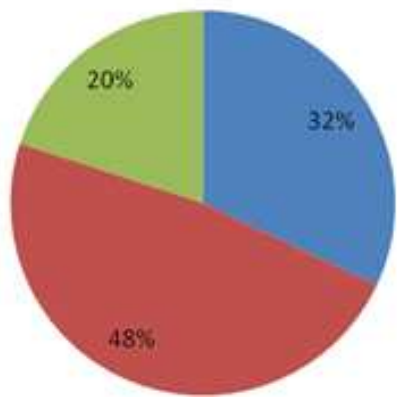

Types of presence of students in the classroom Percentage

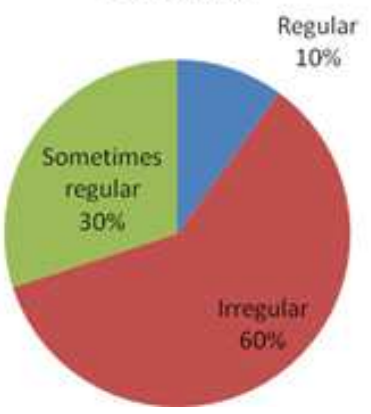

Fig 2. The distribution about seating capacity and types of presence of students.

According from the table and diagram, seating capacity in the classroom is in the range $50-60$. It is good for small in number bad for large in number of students, and most students are irregular in their class. It is very dangerous for effective classroom teaching.

\subsection{Identification of the Limitations of Effective Classroom Teaching in Govt. Colleges in Dhaka City}

Some primary data have been collected from 500 respondents who are teaching in different Govt. colleges in Dhaka city. These data are shown below in the form of tables.

Table 3. The distribution of causes of being irregular in the classroom and About preparing lesson plan before attending the class

\begin{tabular}{lcc}
\hline Type & No. Respondents & Percentage \\
\hline Private tuition & 280 & $56 \%$ \\
Lack of teacher & 130 & $26 \%$ \\
Student politics & 090 & $18 \%$ \\
About preparing lesson plan before attending the class & \\
\hline Yes & 150 & $30 \%$ \\
No & 350 & $70 \%$ \\
\hline
\end{tabular}

According to this table, the main cause of irregularity of students is private tuition. It is also obstacle for effective classroom teaching and about $70 \%$ respondents don't prepare lesson plan before attending the class. It can't ensure effective classroom teaching.

Table 04. Types of teaching methods following in the classroom

\begin{tabular}{lll}
\hline Type & No. Respondents & Percentage \\
\hline Lecture & 250 & $50 \%$ \\
Question - Answer & 110 & $22 \%$ \\
Problem solving & 040 & $08 \%$ \\
Pair - Work & 010 & $02 \%$ \\
Group work & 080 & $16 \%$ \\
Presentation & 010 & $02 \%$ \\
Panel discussion & 005 & $01 \%$ \\
Total & 500 & $100 \%$ \\
\hline
\end{tabular}

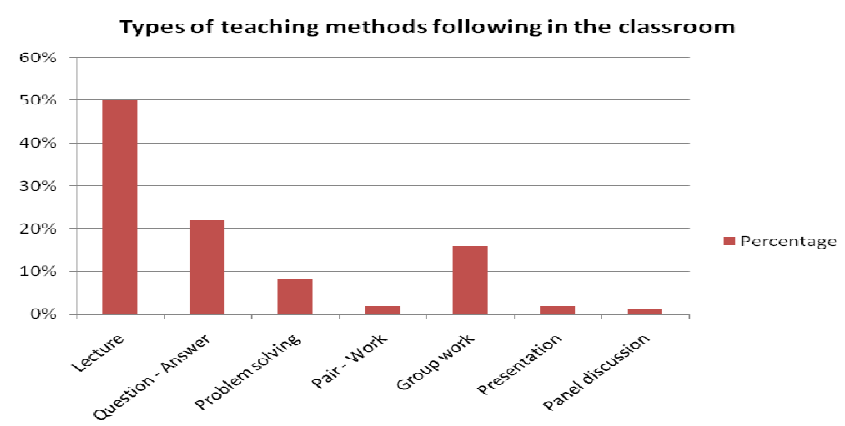

Fig 3. Types of teaching methods following in the classroom 
According to this table, about 50\% respondents follow the traditional teaching method like lecture. To ensure effective classroom teaching, modern and up to date teaching methods must be followed in the classroom.

Table 5. Necessity of teachers' training

\begin{tabular}{lcc}
\hline Type & No. Respondents & Percentage \\
\hline Yes & 480 & $96 \%$ \\
No & 020 & $04 \%$ \\
Total & 500 & $100 \%$ \\
\hline
\end{tabular}

Necessity of teachers' training

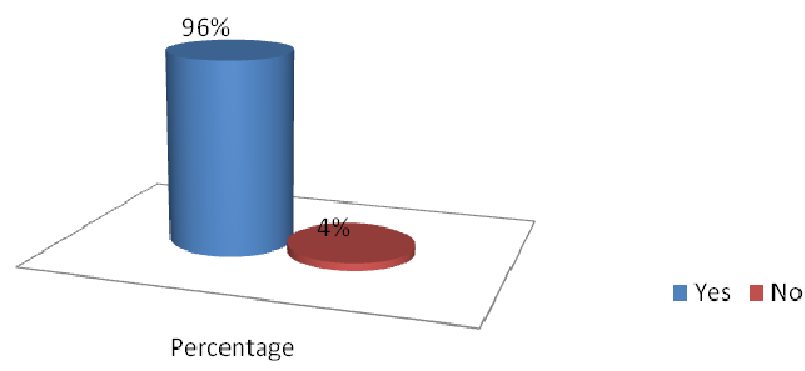

Fig 4. Necessity of teachers' training

According to this table and diagram, about $96 \%$ respondents think that they need training to ensure the effective classroom teaching.

\section{Findings}

Having done this study some problems are identified regarding effective classroom teaching. These are as follows:

- Teachers face various problems while taking class in the classroom.

- Students' absenteeism is the most serious problem in the effective classroom teaching.

- Most of the students do not go to the class regularly. Private tuition is the main cause.

- Lack of teacher and updated teaching aid are hampering classroom teaching.

- Most of the teachers don't prepare lesson plan before attending the class.

- Teachers follow traditional teaching method like lecture method.

\section{Recommendations}

Modernization and restructuring of education system are main ways and means to proper education. The following recommendations should be considered.

- Well equipped attractive classroom with updated teaching aids.

- Students' participation in the classroom should be ensured to build up teacher-student relationship.

- Impose co-curricular and extra-curricular activities.

- Increase no. of properly trained teachers.

- Teacher must follow the proper teaching method in the classroom. The must prepare lesson plan before attending the class.

- Political disorder in the Govt. colleges should be removed.

\section{Concluding Remarks}

College education is one of the most important subsectors in education. The quality education depends mostly on the classroom teaching. So classroom teaching should be effective. It is the fact that the classroom teaching in Govt. colleges are not satisfactory. Teaching-learning process at classroom is the most important factor for improving the quality education. Many seminars, symposiums have been held on regarding quality education, curriculum etc. but nobody speaks of the problems of the effective classroom teaching. This study will be successful and fruitful only when will help the nation to be aware about the improvement of effective classroom teaching.

\section{References}

[1] Copper, J. Can research-based teacher evaluation be saved? Journal of Personnel Evaluation in Education, 1970, 4(1), $19 \pm 39$.

[2] Du, P. K. Research-based teacher evaluation: A response to Shriven. Journal of Personnel Evaluation in Education, 2002 $4(1), 7 \pm 18$.

[3] Berk, R., Fifty reasons why student achievement gains does not mean teacher effectiveness. Journal of Personnel Evaluation in Education, 1898 ,1(4) 345 \pm 364 .

[4] Brophy, J., Teacher in ${ }^{-}$uences on student achievement. American Psychologist October, 1968, 1069 \pm 1077.

[5] Ali, M. A., Supervision for teacher development: An Alternative Model for Pakistan. International Journal of Educational Development 20, 2000, 177-188

[6] Aly, J.H., Education in Pakistan: A white paper revised draft document to debate and finalize the national education policy. Islamabad: National Education Policy Review Team, 2007.

[7] Berliner, D.C. Effective classroom management and instruction: A knowledge base for consultation. Washington, 1998.

[8] Canter, L., \& M. Canter. Assertive discipline: Positive behavior management for today's classrooms. 3rd ed. Seal Beach, CA: Canter 2001.

[9] Dreikurs, R., B. B. Grunwald, \& F. C. Pepper. Maintaining sanity in the classroom: Classroom management techniques. 2nd ed. Washington, DC: Taylor and Francis, 1998.

[10] Edwards, C. H. Classroom discipline and management. 4th ed. New York: John Wiley and Sons, 2004. 
[11] Froyen, L. A., \& Iverson, A. M. Schoolwide and classroom management: The reflective educator- leader (3rd ed.). Upper Saddle River, NJ: Prentice-Hall, 1999

[12] Feldman, J. R. Wonderful rooms where children can bloom. Peterborough, NH: Crystal Springs Books, 1997.

[13] Froyen, L. A., \& Iverson, A. M. School wide and classroom management: The reflective educator- leader (3rd ed.). Upper Saddle River, NJ: Prentice-Hall.1999

[14] Gallagher, J. D. (1998). Classroom assessment for teachers. Upper Saddle River, NJ: Merrill, 1998.

[15] Ishtiaq, H. Teachers can make a difference. The Dawn. Retrieved June 22, 2012, from www.dawn.com

[16] Ingersoll, R. M., and T. M. Smith. The wrong solution to the teacher shortage. Educational Leadership, 2003, 60 (7): 10 22.

[17] Jones, F. Tools for teaching. Santa Cruz, CA: Fredric H. Jones \& Associates, 2000

[18] Krause, K. L., Bochner, S., \& Duchesne, S. Educational psychology for learning and teaching. Australia: Thomson, 2003.

[19] Lewis, R., Teaching and Teacher Education Classroom; Discipline and Students Responsibility. The students view 17, 2000, P. 307-319
[20] Muhammad, T. \& Ismail, M. Violence against Children within the Family \& in Schools. Committee on the Rights of the Child. September 28. OHCHR, Geneva: NGOs Coalition on Child Rights-Pakistan, 2001, No.2

[21] Omar E, H. (2000). Improving the quality of learning: global education as a vehicle forschool reform. Theory into Practice, 2000, 39(2): 97-103.

[22] Classroom schedules (What Works Brief Series, No. 3). Retrieved on dated May 12, 2012 from http://www.adprima.com/managing.htm

[23] Riaz, I. Implementing the new Education Policy 2009. The Dawn. Retrieved July 20, 2012, from www.dawn.com

[24] Saad, I. Education in Pakistan. Pakistan prospects and perspectives. Karachi: Royal, 1999.

[25] Tan, A. (2001). Elementary school teachers' perception of desirable learning activities: A Singaporean perspective. Educational Research. 2001, 43 (1), 47-61.

[26] Tan O.S., Parsons, R.D., Hinson, S.L., \& Sardo-Brown, D. Educational psychology: A practitioner- researcher approach. Australia: Thomson, 2003

[27] Santrock, J.W. Educational psychology: Classroom update: Preparing for PRAXIS TM and practice. (2nd ed). New York:Mc Graw Hill, 2006 